\title{
Recreational potential of the regulated watercourse Ostravice river in Ostrava urban area
}

\author{
I. Lampartová ${ }^{1)}$, J. Schneider ${ }^{1)}$ \\ 1) Department of Landscape Management; Faculty of Forestry and Wood Technology, Mendel University \\ in Brno, Zemédèlská 3, 61300 Brno,e-mail:ivana.lampartova@mendelu.cz
}

Abstract: Lampartová I., Schneider J. 2014: Recreational potential of the regulated watercourse Ostravice river in Ostrava urban area. Beskydy, 7 (2): 69-80

\begin{abstract}
Water coursess are segments in the country increasing its recreational potential. The current goal of revitalization measures in the landscape primarily consists of the optimization of landscape water regime, incl. flood control measures and the promotion of biodiversity, but the current philosophy speaks of multifunctional land usage. In the society there has been indicated the necessity for recreation, because a large part of the population lives in urban settlements and is employed in an artificial technical environment that has largely inadequate sanitary conditions (unfavourable microclimate, noise, dust, etc.). Recreation as a social phenomenon is therefore a permanent part of the lifestyle in economically developed countries. However, the revitalization is currently underappreciated in the Czech Republic and it is important to increase recreational potential of the landscape. The subject of this article is evaluation of regulated watercourse Ostravice river in Ostrava urban area. The model area of river Ostravice in Ostrava regionis describedhere.Inthemodelareais evaluated some elements of recreational potential of revitalization by the proposed methodology. The outcome of the work is to propose an ongoing systematic procedure for assessment of the relevance of revitalization actions in terms of the recreational potential of the landscape and their impact on the development opportunities of the region.
\end{abstract}

Keywords: revitalization measures, recreational potential, evaluation methodology, revitalization of the Ostravice river

\section{Introduction}

For recreation and tourism it is necessary to determine a suitable potential of a particular area. According to Novotná (2005), potential of a landscape is understood as the landscape ability and its fitness. For example, by the term socio-economic potential of the landscape we understand the fitness of all the landscape components to provide a variety of needs of the society, including recreation itself.

The studied landscape system of water features has a different potential for individual human activities. In this work we speak about potential of the landscape and its suitability for recreational activities - specifically about the recreational potential of water features within their revitalization.

Revitalizing measures leading to riverbanks and floodplain alterations have a significant impact on recreation and creation of social security and facilities of the area. Furthermore they are an important natural and aesthetic component of the landscape. These revitalization measures (bio/technical, biological parameters) affect recreation (landscape perception) and creation of the landscape (structure and landscaping). Revitalizing treatment of riverbanks and inundation areas allow to increase the recreational potential of the area. However, the actual 
recreation indicators and landscape character is not a condition for revitalization of river banks and floodplains.

Promoting recreation and tourism in the area leads to the development of rural areas. The study by Reeder, Brown (2005) examines the socio-economic conditions of the impact of recreation and tourism on the countryside. Findings of these experts suggest that leisure time and tourism contribute to rural contentment, leading to an increase in local employment, wage growth and income, reducing poverty and improving education and health. But the development of recreation and tourism is not without drawbacks. It increases e.g. housing costs, the traffic load, environmental pollution, overloaded capacity in services. Local effects varies significantly depending on the type of the recreation area.

The demand of human population for recreation and tourism in natural ecosystems gradually increases worldwide. Reed, Merenlender (2008) indicate an urgent need for new approaches to define the management and limits for recreation and tourism, especially in areas extending into protected areas. The research has shown that the increasing growth of recreation and tourism in these areas damages not only environmental components such as water features, soil, but also representation of species, the occurrence and reproduction of fauna and flora. It is necessary to configurate recreational trails in these areas, which will be contributive when determining the subsequent recreational impact on the monitored landscape.

However, equally important is recreational potential of green areas within residential structures. Water elements are their important parts, whether natural or artificial, linear, planar or spot. Rivers are very important as they affect the landscape and the city to a varying extent, including both local and regional conditions. Their main social benefits are not only a source of water for human activities (industrial, agricultural, etc.), transportation corridors or organisms (and often pollution), but also a historically long-term recreational use. In addition to the riverbed itself, bank alterations and the character of the waterfront have an important function. However, rivers and their surroundings in cities face a lot of pressure on space and above all on flood control modifications. This increases the importance of work of urban planners and water managers to find an optimal solution to use not only the waterfront, but also the inundation zone, into which the whole city often falls. Nevertheless, it is necessary to be able to maintain and respect the recreational potential of the river and its surroundings.

As a matter of course in historical city centers rivers are historically and in an urban manner incorporated into the overall structure where they make a significant value not only in terms of recreation potential, but also in terms of tourism potential. For local residents, however, sections of rivers outside the main tourist zone are particularly essential that are of little or no important touristic value, but still there can be found either a resting area or on the contrary a river and its surroundings which significantly enhances a positive character of the city for its residents (a typical example might be the Svratka river in Brno under the Kníničská dam or the river Ostravice in Ostrava. Nevertheless this phenomenon can be found only in big cities outside the historical centres). Therefore it is important to be able to determine the value of the recreational potential of the river system in an urban environment and be able to encourage and develop it further.

Over the past years many different restoration actions have already taken place for which considerable financial resources have been spent. This is in accordance with Vrána (2004) one of the main reasons for the need to establish an objective method of effect evaluation of revitalization activities. It is desirable to develop a methodology for quantifying the success and effectiveness of restoration actions, which would clearly concretized the target state and the procedure to evaluate the effectiveness and success of implementation.

Currently there are several methods to evaluate the revitalization effect. For the purpose of evaluating the revitalization success are mainly used methods of expert evaluation. These of course vary according to the specific objectives and the nature of revitalization measures (Holl and Cairns 2002).

Kupec, Schneider, Šlezingr (2009) emphasize, however, that none of these measures apply universally, and it is always necessary to take into account local conditions, the purpose and scope of revitalization. For a successful evaluation of the revitalization project it is necessary to know the status of the site before the revitalization, but it is not always available. For this reason, most methods work with "reference state", or are based on the expertise of the evaluator. 
Therefore the results of the methodologies are usually not quite exact. An objective assessment of the effect can be reached by evaluating the flow parameters before and after the revitalization. When the flow is being rated, the following flow parameters are usually taken into account: river bed morphology, water flow recovery, water quality in the watercourse, vegetation, incorporation of the landscape and other integration measures in the catchment area of the revitalized section.

The overview of the methodologies used to evaluate the revitalization effect actions on water elements are available, e.g. on the website of the Ministry of Environment.

The need for recreational potential of the landscape is based on the individual and societal demands of the population. It is more intensive in large cities where many people do not own large plots. In the concept of revitalization adjustments rivers and their surroundings can serve as public natural parks and gardens and replace the lack of contact of people with nature. The objective of revitalization measures in the landscape lies nowadays primarily in flood protection measures and the promotion of biodiversity. The revitalization of watercourses are of a great importance in terms of increasing the recreational potential of the landscape, which is nowadays in the Czech Republic yet underappreciated.

Evaluation methodologies of the recreational potential are used to define a part of the territory, which may increase their attractiveness mainly for visitors and locals. The status of the area is evaluated and assessed in terms of importance for the quality of the landscape, which may be positive, neutral or negative. The negative effects disturb the landscape, landscape elements seem to be heterogeneous and give inaesthetic impression. In addition, they can limit the recreational use of the landscape area. It has a very low or zero recreational potential. The positive effect of landscape features is an increase in the recreational potential of the territory creating an attractive impression and it attracts the attention of visitors. Neutral recreational potential is such a condition that neither affects nor in any way contributes to the possibilities of its use.

For the purposes of the landscape evaluation in terms of recreation potential, attractiveness and its use, the following methodologies are most often applied: Evaluarion of the recreational potential by TERPLAN method (natural recreational potential of the landscape)
(Kolektiv 1974), Evaluation of the tourism potential (Vepřek 2002), Methodological construction of evaluation of the tourism potential (Bína 2002). Methods according to Vepřek and Bína evaluate the potential of tourism, which is based on the recreational potential of the landscape, but it also includes the currently preferred recreational activities. Furthermore "Methodology of possibilities of using landscapes" is used.

Another method used is e.g. A method for assessing tourist potential by Pralong (2005). This method is particularly suitable for assessment of similar sites. In principle it is based on comparing values of the monitored area among themselves. The method evaluates the importance of tourism and its components (scenic, scientific, cultural and economic). A method for assessing tourism potential by Ciurea $\mathrm{et}$ al. (2011) is based on four evaluation criteria (natural, anthropological potential, specific tourism infrastructure and specific technical infrastructure). The amount of the potential is then determined using a rating scale that consists of four levels (very high, high, average, low potential).

It is a complementary method to quickly and tentatively compare two landscape areas. The disadvantage of this method is the subjectivity of the evaluation.

A part of the recreational potential of an area is the character of the landscape. Water features are an inseparable part of the landscape and contribute to its creation. Landscape character expresses natural, socio-economic and cultural-historical relations of the landscape characteristics. Taking care of the landscape must be applied even in urban areas, where the landscape is of an important value. It's not just protected areas and natural parks, but also waterway corridors, forest and agricultural land (Vorel et al. 2004).

In the Czech Republic there is no precisely defined way in which the landscape could be assessed, but there is a wide range of methodologies from many authors. These include the works of Vorel et al. (2004), Löw, Míchal (2003) and others.

The aim of the article is to present a proposal of a possible assessment of the impact and importance of watercourses revitalization in urban and sub-urban areas on recreation potential, value and the use of landscape on the example of a model area in the vicinity of the Ostravice river. Primarily the evaluation of revitalization actions taken on watercourses will be dealt with on the basis 
of the analysis, comparison and synthesis of contemporary utilitarian methods. The following procedures will be used: monitoring hydromorphological indicators of ecological quality of watercourses, evaluation of implemented restoration actions - selected watercourses and small lakes, assessing the state of riverbanks - index of river quality QBR (F.E.M. Research Group, 2000) and evaluation of the current state of riparian vegetation along the watercourse. At the same time recreation potential of the landscape and tourism will also be assessed through available current methods and by criteria evaluation then geographical, landscape-natural, cultural and heritage value of the area.

For the selection of evaluation indicators in terms of landscape and the landscape character will be used the methodology for assessing the impact of proposed buildings, activities or changes in land use on the landscape.

\section{Materials and methods}

\section{Locality}

Unlike our neighbouring countries, such as Germany, Austria, Poland, the revitalization in the Czech Republic to improve recreational potential so far focuses only on small watercourses. A model example is the river basin of the river Ostravice, which highlights the development of the idea of increasing the recreational potential in the framework of revitalization of watercourses on a wider scale.

Ostravice (Ostrawica in Polish, in German Ostrawitza) is a river rising in rugged mountainous relief of the Moravian-Silesian Beskids. In this section of the river basin there is a part of the protected landscape area of the Beskids. Than it flows through Lysohorské podhưří, Podbeskydská pahorkatina, and subsequently through the Ostrava floodplain formed by strata of sand and gravel and sand-soil sediment load. These sections are significantly affected by rural and then urban housing developement. The lower reaches is strongly influenced by the anthropically urbanized industrial-residential landscape of Ostrava significantly affected by industrial activities. Despite all the anthropogenic influences and interventions the river Ostravice with its riverside zone forms an irreplaceable biocorridor of a wetland and aquatic biota of a great importance for the environment quality of the central part of Ostrava. The river
Ostravice forms partly the historical border of Moravia and Silesia (Buček et al. 2011).

The evaluated model locality is the revitalization of the river Ostravice flowing through the center of Ostrava. Ostrava has a unique position within the cities in the Czech Republic, as it is one of the few cities situated at the confluence of four rivers - Ostravice, Lučina, Odra and Opava. The nature of the city of Ostrava is determined by these rivers. Ostrava City is currently implementing a set of many different projects that lead to the revitalization of the river Ostravice and its immediate surroundings. The projects are also a part of the Integrated Urban Development Plan of the city of Ostrava - Magnet for the region. Activities of the Ostrava City, in cooperation with the Odra River Basin (state enterprise), will bring, through these planned modifications, the river Ostravice closer not only to people, but they will also contribute to the improvement of the environment and the river will benefit from it. The initiator and investor of the extensive actions are jointly the City of Ostrava, Ministry of Finance CR, the Association of boaters Campanula (civic association) and the European Union. The Agency for Nature Conservation and Landscape also cooperates and proposes various compensatory measures.

The main reason for choosing this location was the intention of the mentioned revitalization project. This is not a project focused primarily on the optimization of the landscape water regime, flood protection, or encouraging biodiversity. It mainly deals with multifunctional land use, including the revitalization of the utmost importance in order to increase the recreational potential of the area, which is nowadays underrated in the Czech Republic see Fig. 1. Based on the experience with application in practice, the methodology will be further specified (particularly in the potential coefficients and weights of criteria).

\section{Method}

The goal and the expected outcome of this work is to propose an ongoing methodology for the assessment of the importance of revitalization measures in terms of recreation potential of the landscape, and therefore their influence on the development opportunities of the region. This provisional proposal will be created on the basis of the analysis of practical examples of revitalization in the Czech Republic and abroad, field research, comparison and synthesis of existing evaluation methodologies. 


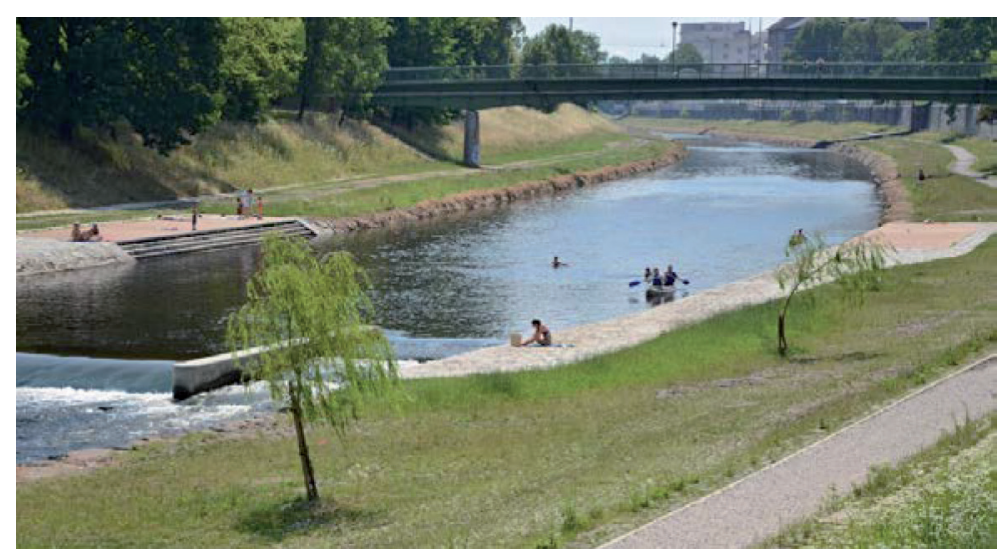

Fig. 1: Restoration modifications of the model locality - Ostravice river in the center of Ostrava.

For the proposal of a methodological evaluation procedure of revitalization, evaluation indicators will be selected from methodologies for the evaluation revitalization actions, landscape and recreational potential of the area. To determine the significance of revitalization measures in terms of recreation potential of the landscape, the following combination of methodologies has proved suitable:

A. Methodology for assessing the effectiveness (success) of revitalization

- Methodology (HEM) Hydroecological monitoring (Langhammer 2008),

- The evaluation methodology of implemented revitalization actions - Selected waterways and small water tanks - (Vrána, Dostal, Vokurka 2003)

- The method of assessing the state of the riparian area - QBR index of river quality (F.E.M. Research Group 2000)

- The method of evaluation of the current state of riparian vegetation of the watercourse (Šlezingr, Úradníček 2002)

B. Methodology for assessing the recreational potential (or potential tourism)

- Assessment of recreational potential by the method of TERPLAN (natural recreational potential of the landscape) (Kolektiv 1974)

- Evaluation of the potential of tourism (Vepřek 2002)

- Methodical construction of evaluation of the tourism potential (Bína, 2002)

C. Methodology for assessing the landscape character
- Methodology for assessing the impact of the proposed construction, activities or changes in land use on the landscape character (Vorel et al. 2004).

To create a system of criteria, groups of indicators from the (HEM) methodology were mainly used, e.g. the river bed and the flow path, the bottom, the bank and the inundation area, flow and the hydrological regime. Furthermore, the methodology used by Bína e.g. (2002) suitability of land for recreation and the presence of social amenities and security. From the perspective of the landscape character according to Vorel et al. (2004) were selected indicators of natural, cultural, historical and aesthetic characteristics (Lampartová, Schneider 2014).

\section{Results}

The outcome of the work is to propose an ongoing systematic procedure for assessment of the relevance of revitalization actions in terms of the recreational potential of the landscape and their impact on the development opportunities of the region. The result is a complex evaluation table that contains indicators and their criteria. The selection of these indicators and criteria has been carried out on the basis of the analyses of practical examples of revitalization in the Czech Republic and abroad, field research, comparison and synthesis of existing evaluation methodologies.

The project of the City of Ostrava "Revitalization of the river Ostravice" aims to revitalize the river in the district of Ostrava so that it can serve the residents and visitors 


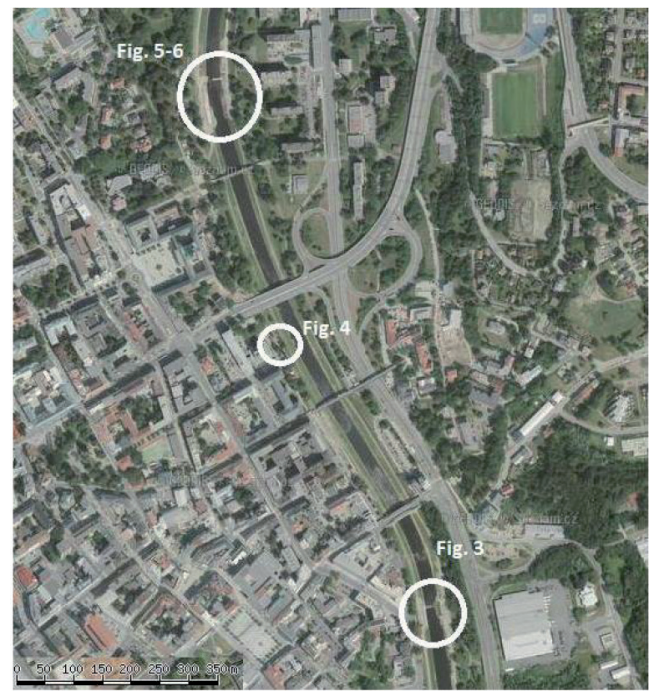

Fig. 2: Aerial photograph showing the restoration modifications of the model locality - Ostravice river in the center of Ostrava.

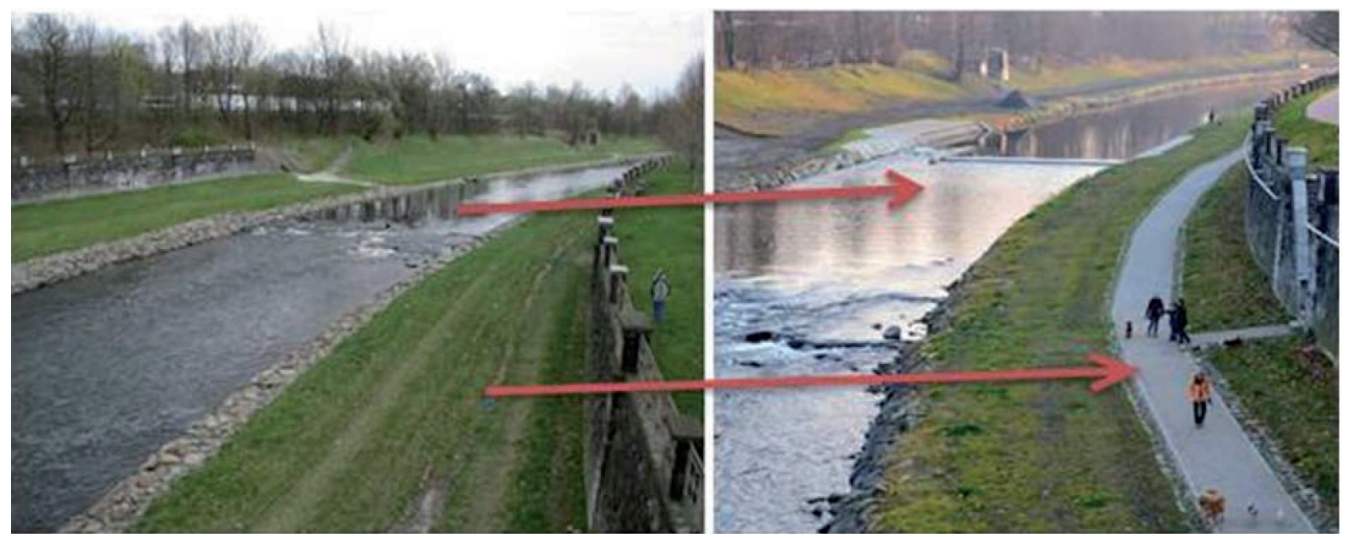

Fig. 3: Weirs with the fish passage under the bridge Sýkora, walking trails and multi-purpose communication.

of the city as a place to spend their free time at, do sports and also for environmental education. The photo examples below demonstrate the influence of the revitalization of the watercourse in order to increase the recreational potential and development of the city of Ostrava. These photographs were taken before and after the adjustments within the project "Revitalization of the river Ostravice" (Lampartová, Schneider 2014).

The purpose of the construction of weirs in the project "Revitalization of the river Ostravice" was to create a water mirror by swelling the water surface and thus setting conditions for recreational activities and relaxation of inhabitants and visitors of the city of Ostrava. Water levels (dams) supplemented by fish passages are used for example by members of the boating club Campanula o.s. The banks around the dams are adapted for movement and recreation of the citizens by stone tiles and wooden piers. The surrounding area is planted with vegetation elements.

The weirs are accessible thanks to new or reconstructed steps into the berm, tackled under the construction of a "Cycle track". Within the project hiking trails and multi-purpose communications for hiking and cycling were built in the section from the confluence of Lučina Ostravice to Koblovský bridge. These hiking trails can be used for cross-country skiing in the winter. All these mentioned revitalizing 

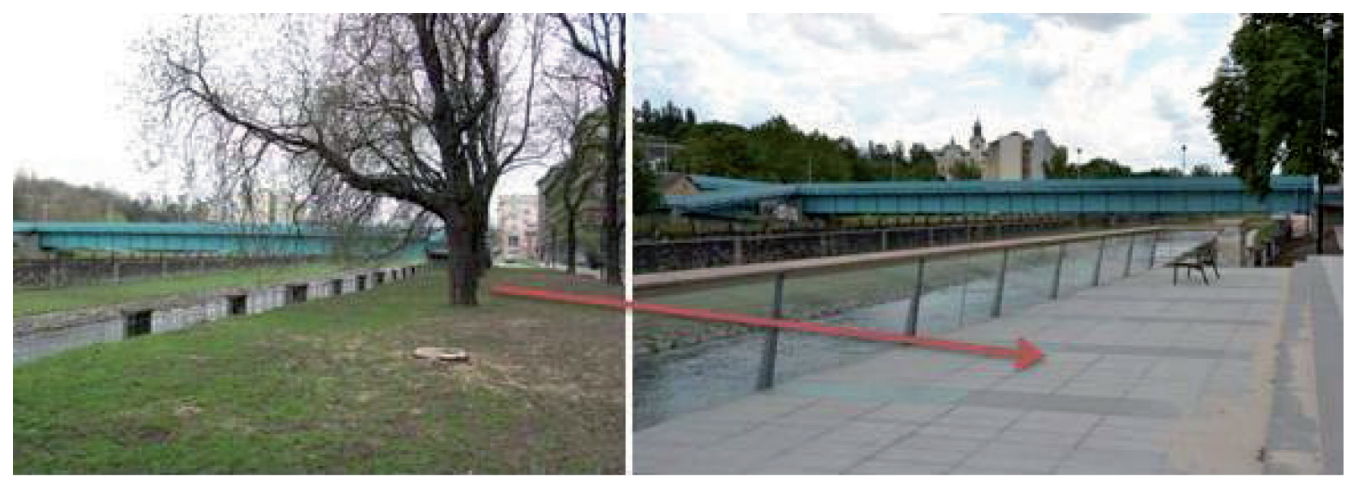

Fig. 4: Observation gallery.

elements are evaluated positively within the proposed methodology and they are most suitable for recreation in this area. In the framework of recreational land use it is also possible to carry out additional forms of recreation such as bird watching and aquatic animals, photography, sunbathing and relaxing.

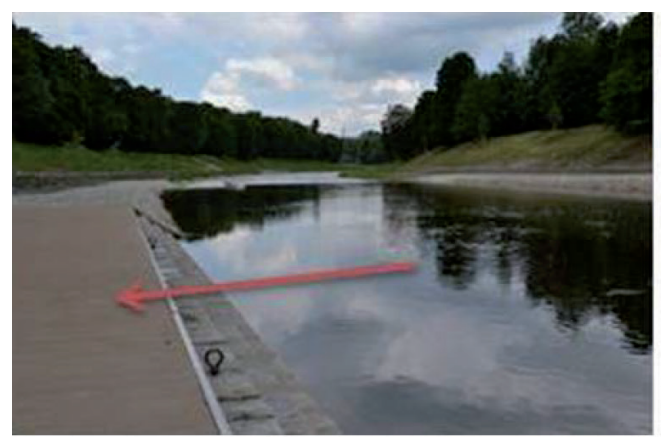

Fig. 5: Boating and Sunnit pier, fish passage.

A part of the project documentation is a new concept of pedestrian and automobile traffic outside the County Court and the Havlíčkovo waterfront. In the study "Cycle tracks and related pedestrian and access roads", there is a complete renovation of the space - new paving, lighting, street furniture. This observation gallery, which opened up new views of the river Ostravice, was built within the project. The observation gallery is wheelchair accessible. It thus offers all visitors a place to relax, sunbathe, watch and photograph birds and the landscape. Under the proposed methodology the construction is evaluated very positively and the resort is very suitable for recreation.
The newly built water sports piers serve as a stop for paddlers, and for all citizens as areas for relaxing and sunbathing. There is an access to every proposed pier and weir. They are either exits into an existing berm or newly reconstructed steps into the berm, tackled under the construction of "Cycle tracks". The existence

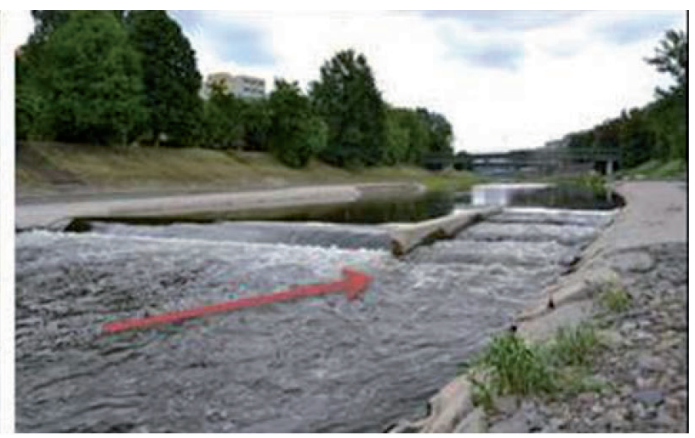

of paths and wheelchair accesses to the water element is evaluated very positively in the proposed methodology. The presence of water piers in the river is decisive for water tourism.

Accesses to the weirs and piers are through new or reconstructed steps into the berm, tackled under the construction of "Cycle tracks". The existence of steps to the water element is evaluated very positively in the proposed methodology. However, within the construction it is necessary to resolve safety rails.

Within the framework of the river Ostravice revitalization, the banks were revitalized and reinforced with stone pavement, which can serve the citizens as a place to relax and enjoy the sun by the watercourse. These elements along the river banks are important not only 

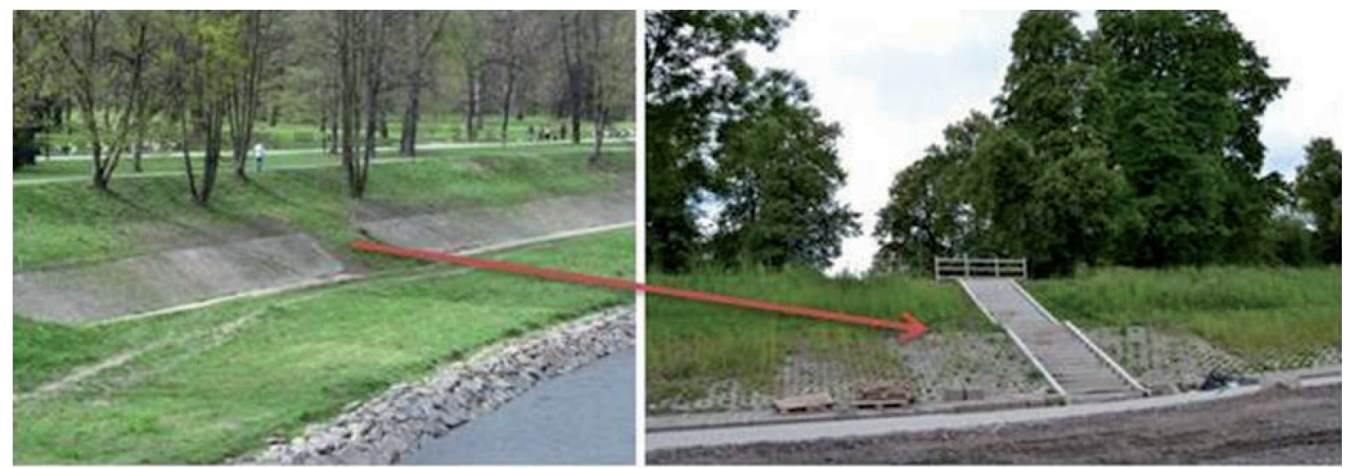

Fig. 6: Access to the water element.
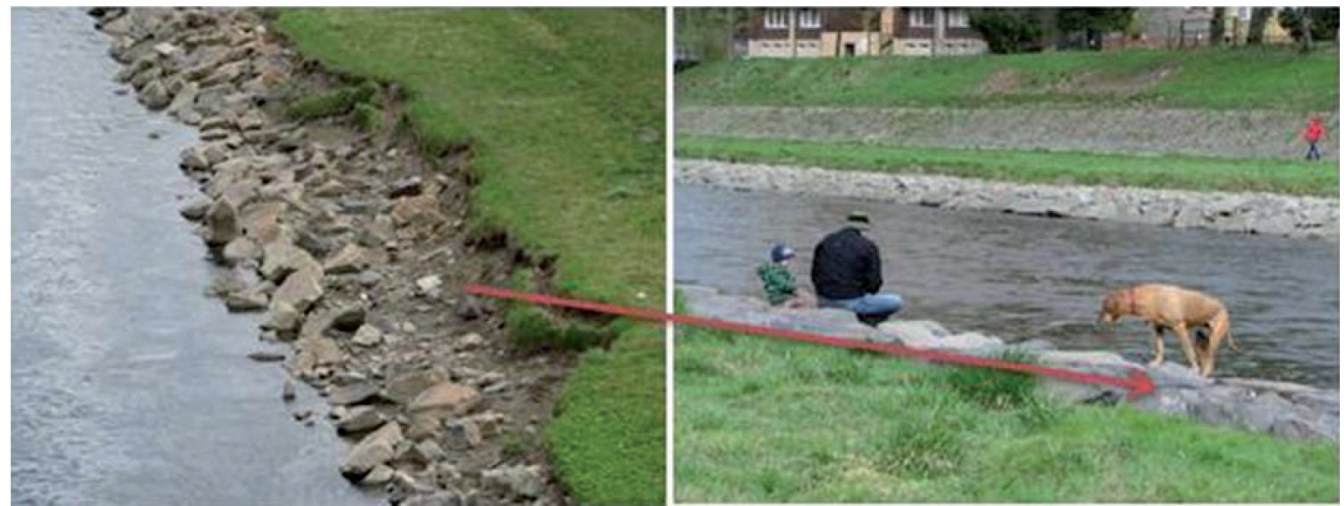

Fig. 7: Modifying riparian defenses.

to strengthen, but also to increase the "wet circuit". It is important for the possible presence of aquatic animals and plants. It also helps the process of self-purification of water. Under the proposed methodology the reinforced stone pavement is found very appropriate in terms of revitalization, ecology and recreation.

To enhance the recreational potential of the area, the project "Revitalization of the river Ostravice" has dealt with the following measures:

- Construction of terraced galleries,

- construction of piers for boaters,

- construction of two weirs in order to ensure increasing water levels,
- construction of sport water gates for boaters,

- ensure the recovery of the natural swimming pool with sunbathing areas, gravel beach,

- providing social facilities in the form of a tourist restaurant,

- pedestrian promenade,

- construction of roads and trails for walkers, cyclists and skaters.

The result of this work is to evaluate the effect of some revitalization measures, see (figs. 3-7) on the Ostravice river in terms of recreation potential, see Table 1 . The evaluation was made on the basis of a few selected indicators and criteria of the above mentioned

Tab. 1: Point scale of assessing the suitability of recreation conditions.

\begin{tabular}{lcl}
\hline $\mathbf{0}$ & Quite appropriate & The conditions are quite inappropriate for this kind of recreation \\
$\mathbf{1}$ & Less appropriate & The conditions are less appropriate/limited for this kind of recreation \\
$\mathbf{2}$ & Appropriate & The conditions are fulfill the requirements for this kind of recreation \\
$\mathbf{3}$ & Determining & The conditions are determining for this kind of recreation \\
\hline
\end{tabular}


methods. The indicators and criteria were rated according to suitability of conditions for recreation on the scale from $0-3$, see Tab. 1 . Scoring of indicators and criteria see Tab. 2 was carried out on the basis of the subjective opinion of the evaluator. The individual measures are not a condition of recreation, but they affect it greatly. That is why some indicators are established in the range between two values. For future comprehensive and detailed assessment it will be necessary to determine the weights of individual values.

The construction of the weir with fish ladders scored 2-3 points, as it is quite determining and suitable for water sports (canoeing).

Neatness and bank reinforcement was again rated as quite determining in terms of permeability, accessibility of the watercourse, walking and cycling. This is mainly due to assessment from safety reasons. In addition the selected bank reinforcement can also be used for other recreational activities such as sunbathing, relaxing, watching birds and water animals and photography.

Planting of riparian vegetation is not determining for recreation, but it is very appropriate because of creation of suitable microclimatic conditions within the territory. In summer for example, it protects visitors from the sun and in winter from bad weather-wind.

The river is located in the center of Ostrava, which affects the microclimate of the area, sanitary conditions, noise and attendance. Yet the river is an integral part of the city, and therefore the conditionsforrecreationinurban areas are classified between less suitable to suitable. Constructions leading across and along allow access of visitors to the evaluated area, however, they disrupt the aesthetic and sanitary conditions of the area. This indicator was evaluated in the range between one to two points.

Building a boating pier is considered within the evaluation as fully determining for water tourism. In addition, it serves as a resting and sunbathing area for visitors. Installing movables is found very useful in the area. E.g. lighting allows the use of hiking trails in the evening.

The construction of paved roads, stairs with handrails and barrier-free access to the watercourse is entirely determining for recreation of e.g. disabled people, parents with pushchairs, even for the retired. It is also determining e.g. for cycling and in-line tourism. Natural, cultural, historical and aesthetic sights are very useful and they increase the potential for attendance and recreation.
Based on the experience with application in practice, the methodology will be further specified (particularly in the potential coefficients and weights of criteria).

\section{Conclussion and discussion}

The overall outcome of this work was to propose an ongoing methodological procedure to evaluate the importance of revitalization measures in terms of recreation potential of the landscape. The result was the creation of a table showing the evaluation indicators and criteria. This proposal has been formed on the basis of preceding analyses of practical examples of revitalization in the Czech Republic and abroad, field research, comparison and synthesis of existing evaluation methodologies. For the proposal of a methodological procedure of revitalization evaluation were selected assessment indicators from methodologies for the evaluation of revitalization actions, landscape character and recreational potential of the area. The overview of these methods was chosen on the basis of the importance of the individual indicators (eg riparian vegetation, water quality, river bed morphology), as elements in urban areas and the surrounding landscape, which significantly enhance the recreational potential of the revitalized area.

The presented methodology proposal is a partial (ongoing) outcome, which is currently being verified in the field on a model example of the river Ostravice in Ostrava, but also in the revitalization adjustments in the Czech Republic and abroad. The final version is the structure of the criteria used to determine the recreational potential of the revitalization actions. Based on field verification, it is necessary to specify the weight and value of each indicator. It can be assumed that the importance of revitalization actions for recreational potential is largely bound to the spatial extent of the revitalization. Since methodologies for the assessment of recreational potential/ tourism potential do not distinguish between leisure opportunities for local people (mostly short-term recreation - half a day or one day recreation) and recreational potential in terms of visitors (multidays recreation), it will be necessary to incorporate this aspect of the methodology separately in the form of measure of importance - local regional, national (supraregional).

The proposed value scale assumes professional erudition of the evaluator. On the other 


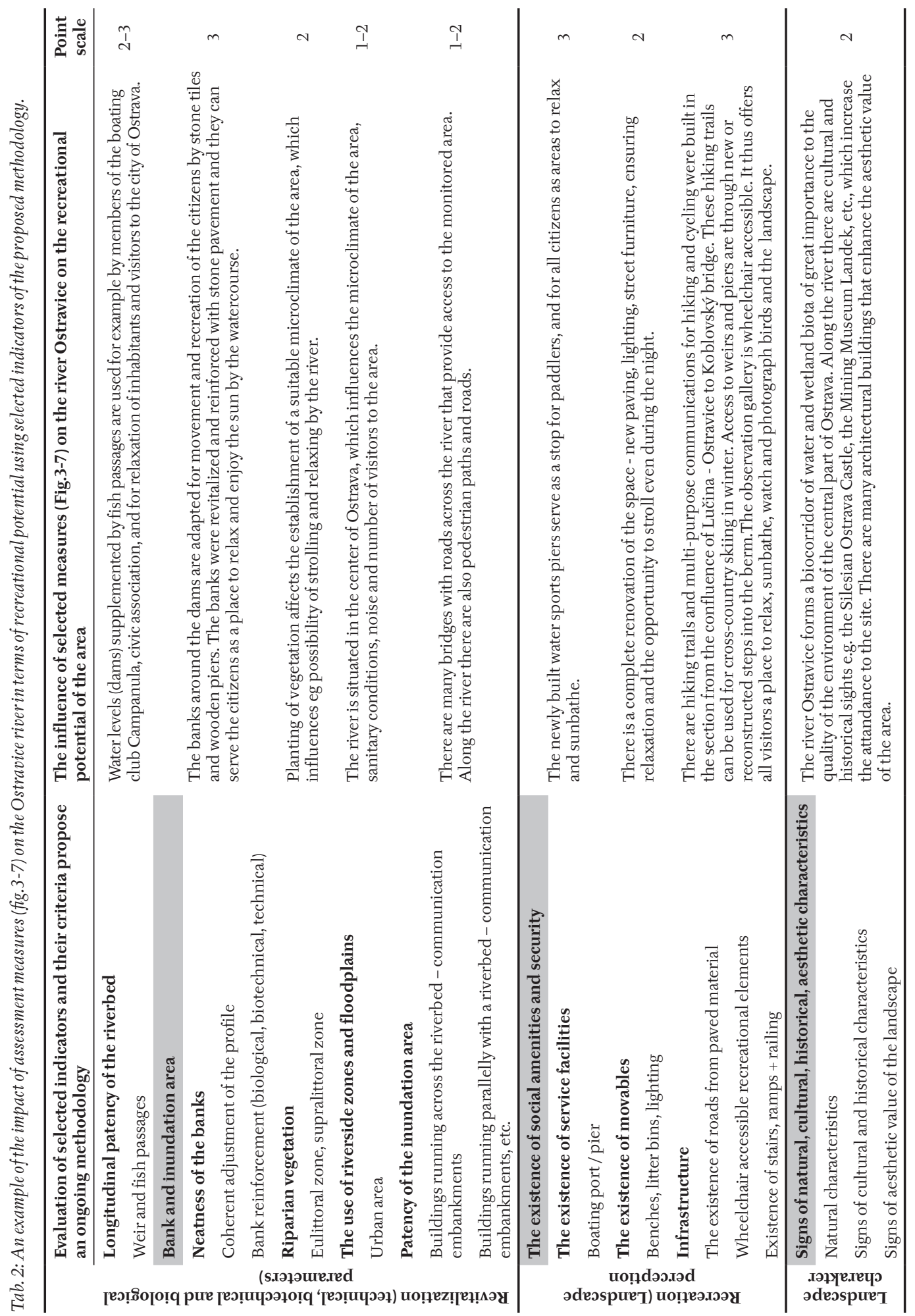


hand, it is easy to apply in practice and provides generally comprehensible results. It can therefore serve as a basis for evaluating the effectiveness of funds spent on modifications of river environment in cities as well as for analytical data processing within regional planning.

\section{Acknowledgement}

This article was prepared within the project IGA FBE Mendel University in Brno "Conflicts of recreation and nature protection in the context of regional development in the area of large especially protected territories."

\section{References}

BínA, J. 2002: Hodnocení potenciálu cestovního ruchu v obcích České republiky. Urbanismus a územní rozvoj [Evaluation of the potential tourism in the municipalities of the Czech Republic. Urbanism and Territorial Development]. 5 (1). http:// www.uur.cz/images/publikace/uur/2002/200201/01.pdf.

Buček, A., Štykar, J., Maděra, P., Vojtek, M., ČERMÁK, P., LoJKÁSEK, B., ĎURIŠ, Z. 2011: Ostravice. [Ostravice]. Brno. http://www.pod.cz/ projekty/flora_a_fauna/Viteze/ostravice_cela.html.

Ciurea, I. V., Mihalache, R., Ungureanu, G., BreZULEANU, S. 2011: Studies Regarding the Evaluation of the Tourist Potential of Oituz Hydrographical Basin - Bacau County. Bulletin UASVM Horticulture, 68 (2): 49-54.

F.E.M. ReseArch Group. 2000: Index of riparian quality: QBR. Universitat de Barcelona. Barcelona.

http://journals.usamvcluj.ro/index.php/horticulture/ article/viewFile/7058/6319.

Holl, K. D., Cairns, J. 2002: Monitoring and appraisal. In. Handbook of Ecolo-gical Restoration, vol. 1. (Eds. Perrow, M. R., Davy, A. J.) pp 411-432. Cambridge University Press, Cambridge.

Kolektiv, 1974: Terplán: Rajonizace rekreace a cestovního ruchu. Praha.

Kupec, P., SCHNeIDER, J., ŠLEZINGR, M. 2009: Revitalizace v krajiné [Revitalization in the landscape]. Brno, Mendel University in Brno, 119 s.

LAMPARTOVÁ, I., SCHNeIDER, J. 2014: The current state of revitalization evaluation of watercourses in terms of recreational potential of the model area of the river Ostravice in Ostrava. Journal of Landscape Management, 5:32-40.

LANGHAMMER, J. 2008: Hodnocení ukazateli: Metodika pro monitoring hyd-romorfologických ukazatelu ekologickékvality vodních tokü. [Evaluation Indicators: Methodology for monitoring hyd-romorfologických indicators of ecological quality of watercourses]. Praha, $23 \mathrm{~s}$. http://www.ochranavod.cz.

Löw, J., Míchal, I. 2003: Krajinný ráz [Landscape character]. 1. vyd. Kostelec nad Černými lesy, Lesnická práce, $552 \mathrm{~s}$.

NovotnÁ, M. 2005: Ohodnocení geografického potenciálu pro cestovní ruch. In Geografie, cestovní ruch a rekreace [Evaluation of geographic potential for tourism. In Geography, Tourism and Recreation]. Olomouc. Palacky University. Department of Geography, Faculty of Science: 15-26.

Pralong, J-P. 2005: A method for assessing tourist potential and use of geomorphological sites. Géomorphologie: relief, processus, environnement http://geomorphologie.revues. org/350?lang=en\#tocto In 2 .

Reed, S. E., Merenlender, A. M. 2008: Quiet, Nonconsumptive Recreation Re-duces Protected Area Effectiveness. In: UC Cooperative Extension. http://ucanr.org/sites/ merenlender/ files/20092.pdf.

REEDER, R. J., BRown, D. M. 2005: Recreation, Tourism and Rural Well-Being. In: USDA Economic Research Service. http://www.ers.usda. gov/media/302182/err7_1_.pdf.

ŠLezingr, M., ÚradníčeK, L. 2002: Vegetační doprovod vodnich tokĩ a nádrži [Bankside trees and shrubs]. Brno CER, $130 \mathrm{~s}$.

VEPŘEK, K. 2002: Hodnocení potenciálu cestovního ruchu a jeho využití v územních plánech VÚC. Urbanismus a územní rozvoj [Evaluation of tourism potential and its use in spatial plans VÚC. Urbanism and Territorial Development] 3: 1-12. http://www.uur.cz/images/ publikace/uur/2002/2002-03/05.pdf.

Vorel, I., BukÁček, R., MatějKa, P., Culek, M., SKLENIČKA, P. 2004: Metodický postup posouzení vlivu navrhované stavby, činnosti nebo zmèny využití území na krajinný ráz. [Methodical process assessing the impact of the proposed construction, activity or land use changes on the landscape]. Praha ČVUT, $22 \mathrm{~s}$.

VRÁNA, K. 2004: Revitalizace malých vodnich tokü: součást péče o krajinu. [Revitalization of small streams: part of landscape management]. Praha, Ministry of the Environment, $60 \mathrm{~s}$.

VRÁnA, K., Dostál, T., Vokurka, A. 2003: Hodnocení realizovaných revitalizačních akcí (vybrané toky a malé vodní nádrže) [Evaluation of realized restoration actions (selected streams and small water reservoirs)]. In NĚMEc, J. [ed.]: Krajinotvorné programy, Praha, 43. ZO ČSOP Praha, 34-46. 
